\title{
A Preliminary Study of Water Quality Index in Terengganu River Basin, Malaysia
} (Kajian Awal Indeks Kualiti Air di Lembangan Sungai Terengganu, Malaysia)

\author{
S. SuRATMAN*, M.I. MOHD SAILAN, Y.Y. HeE, E.A. Bedurus \& M.T. LATIF
}

\section{ABSTRACT}

The Malaysian Department of Environment-Water Quality Index (DOE-WQI) was determined for the Terengganu River basin which is located at the coastal water of the southern South China Sea between July and October 2008. Monthly samplings were carried out at ten sampling stations within the basin. Six parameters listed in DOE-WQI were measured based on standard methods: $\mathrm{pH}$, dissolved oxygen (DO), biochemical oxygen demand (BOD), chemical oxygen demand (COD), total suspended solids (TSS) and ammonical nitrogen (AN). The results indicated the impact of various anthropogenic activities which contribute to high values of BOD, COD, TSS and AN at middle and downstream stations, as compared with the upstream of the basin. The reverses were true for the $\mathrm{pH}$ and DO values. The DOE-WQI ranged from 71.5-94.6\% (mean $86.9 \%$ ), which corresponded to a classification status range from slightly polluted to clean. With respect to the Malaysia National Water Quality Standards (NWQS), the level of most of the parameters measured remained at Class I which is suitable for the sustainable conservation of the natural environment, for water supply without treatment and as well as for very sensitive aquatic species. It is suggested that monitoring should be carried out continuously for proper management of this river basin.

Keywords: Anthropogenic activities; Department of Environment-Water Quality Index; National Water Quality Standards; southern waters of South China Sea (Malaysia); Terengganu River basin

\section{ABSTRAK}

Indeks Kualiti Air-Jabatan Alam Sekitar Malaysia (DOE-WQI) telah ditentukan untuk lembangan Sungai Terengganu yang terletak di perairan selatan Laut China Selatan antara Julai dan Oktober 2008. Pensampelan bulanan telah dilakukan di sepuluh stesen pensampelan yang terletak dalam basin tersebut. Enam parameter yang tersenarai dalam IKA-JAS telah diukur berdasarkan kaedah piawai: pH, keterlarutan oksigen (DO), permintaan oksigen biokimia (BOD), permintaan oksigen kimia (COD), jumlah pepejal terampai (TSS) dan ammonia nitrogen (AN). Keputusan kajian menunjukkan kesan pelbagai aktiviti antropogenik yang menyumbang kepada tingginya nilai BOD, COD, TSS dan AN di stesen yang terletak di bahagian tengah dan hilir sungai, jika dibandingkan dengan bahagian hulu lembangan. Keputusan yang bertentangan diperhatikan untuk nilai pH dan DO. Julat nilai IKA-JAS adalah daripada 71.5-94.6\% (purata 86.9\%) dengan julat status klasifikasinya antara sedikit tercemar ke bersih. Merujuk kepada Piawai Kualiti Air Kebangsaan (NWQS) untuk Malaysia, kebanyakkan aras parameter yang diukur berada dalam Kelas I yang sesuai untuk pemuliharaan mampan persekitaran semula jadi, untuk bekalan air tanpa rawatan dan untuk spesies akuatik yang sangat sensitif. Adalah dicadangkan, pemantauan seterusnya perlu dilakukan untuk pengurusan yang baik bagi lembangan sungai ini.

Kata kunci: Aktiviti antropogenik; Indeks Kualiti Air-Jabatan Alam Sekitar; lembangan Sungai Terengganu; perairan selatan Laut China Selatan (Malaysia); Piawai Kualiti Air Kebangsaan

\section{INTRODUCTION}

The increase in human population densities and the development of industries along the river and coastal areas have increased the pollutant inputs and deteriorated the water quality of the surrounding area (Jindal \& Sharma 2011; Sanchez et al. 2007; Suratman et al. 2009). In addition, the river flow was also monitored as this can influence the water quality of the river system (Sinsock et al. 2003; Sun et al. 2012). River is one of the most important water resources and has many uses such as drinking water supply, agriculture, industrial and recreational activities. In Malaysia, based on the environmental annual report issued by the Department of
Environment (DOE), there are mainly two anthropogenic factors causing river pollution in this country namely land use development and urbanization. These lead to soil erosion and changes in the hydrological regime (DOE 2008). In addition, the introduction of untreated domestic sewage, industrial byproducts and agricultural waste into the river systems have also contributed to the deterioration of river water quality (Lim et al. 2006; Mohd Rozali et al. 2006; Suratman et al. 2009).

In order to monitor and assess the water quality of the river system, many researchers have used the Water Quality Index (WQI) which involves the classification of rivers or river segments into classes of quality in a 
descending order (Pesce \& Wunderlin 2000; Simoes et al. 2008; Suratman et al. 2009, 2005; Zampella et al. 2006). Horton (1965) first proposed the use of WQI and over the years, many different calculation methods have been developed (Inhaber 1975; Landwehr \& Deininger 1976; Smith 1990; Srebotnjak et al. 2012). The index is a numeric expression used to transform a large collection of water quality data into a single index number, which represents the water quality level. A river with high WQI value reflects that the water body is in good condition and vice versa.

Many water quality parameters were used in order to calculate the WQI, such as dissolved oxygen (DO), $\mathrm{pH}$, temperature, biological oxygen demand (BOD), chemical oxygen demand (COD), total nitrate, total phosphorus, ammonia, cyanide, mercury, total suspended solids (TSS) and total coliform (Inhaber 1975; Pesce \& Wunderlin 2000; Sanchez et al. 2007; Suratman et al. 2009). In Malaysia, an evaluation by a panel of experts concluded that only six primary parameters needed to be measured to determine the Malaysian DOE-WQI: DO, $\mathrm{pH}, \mathrm{BOD}, \mathrm{COD}$, TSS and ammonical nitrogen (AN) (Table 1). The DOE-WQI scale classifies the water quality as 'clean', 'slightly polluted' and 'polluted' if the DOE-WQI falls within the range of 81 to $100 \%, 60$ to $80 \%$ and 0 to $59 \%$, respectively. This study adopted the DOE-WQI tool to evaluate the water quality of the Terengganu River Basin. In addition, the beneficial use of the water was also compared with the classification based on the National Water Quality Standards (NWQS) (Table 2). Possible sources from anthropogenic activities which influenced the water quality were also given.

TABLE 1. DOE-WQI calculation formula (DOE 2008)

\begin{tabular}{|c|c|c|}
\hline $\begin{array}{l}\text { Subindex DO (SIDO) } \\
(\% \text { saturated })\end{array}$ & $\begin{array}{r}x \leq 8 \\
x \geq 92 \\
8<x<92\end{array}$ & $\begin{array}{l}\text { SIDO }=0 \\
\text { SIDO }=100 \\
\text { SIDO }=-0.395+0.03 x^{2}-0.0002 x^{3}\end{array}$ \\
\hline $\begin{array}{l}\text { Subindex BOD (SIBOD) } \\
(\mathrm{mg} / \mathrm{L})\end{array}$ & $\begin{array}{l}x \leq 5 \\
x>5\end{array}$ & $\begin{array}{l}\text { SIBOD }=100.4-4.23 \times \\
\text { SIBOD }=108 \mathrm{e}^{-0.055 x}-0.1 \times\end{array}$ \\
\hline $\begin{array}{l}\text { Subindex COD (SICOD) } \\
(\mathrm{mg} / \mathrm{L})\end{array}$ & $\begin{array}{l}x \leq 20 \\
x>20\end{array}$ & $\begin{array}{l}\text { SICOD }=-1.33 x+99.1 \\
\text { SICOD }=103^{\mathrm{e}-0.0157 \times}-0.04 x\end{array}$ \\
\hline $\begin{array}{l}\text { Subindex AN (SIAN) } \\
(\mathrm{mg} / \mathrm{L})\end{array}$ & $\begin{array}{r}x \leq 0.3 \\
0.3<x<4 \\
x \geq 4\end{array}$ & $\begin{array}{l}\text { SIAN }=100.5-105 x \\
\text { SIAN }=94 \mathrm{e}^{-0.573 x}-5 \text { çx-2ç } \\
\text { SIAN }=0\end{array}$ \\
\hline $\begin{array}{l}\text { Subindex TSS (SITSS) } \\
(\mathrm{mg} / \mathrm{L})\end{array}$ & $\begin{array}{r}x \leq 100 \\
100<x<1000 \\
x \geq 1000\end{array}$ & $\begin{array}{l}\text { SITSS }=97.5 \mathrm{e}^{-0.00676 x}+0.05 \times \\
\text { SITSS }=71 \mathrm{e}^{-0.0016 x}-0.015 \times \\
\text { SITSS }=0\end{array}$ \\
\hline Subindex pH (SIpH) & $\begin{array}{r}x<5.5 \\
\times \leq x<7 \\
7 \leq x<8.75 \\
x \geq 8.75\end{array}$ & $\begin{array}{l}\text { SIpH }=17.2-17.2 x+5.02 x^{2} \\
\text { SIpH }=-242+95.5 x-6.67 x^{2} \\
\text { SIpH }=-181+82.4 x-6.05 x^{2} \\
\text { SIpH }=536-77 x+2.76 x^{2}\end{array}$ \\
\hline
\end{tabular}

DOE-WQI $=0.22 * \mathrm{SIDO}+0.19 * \mathrm{SIBOD}+0.16 * \mathrm{SICOD}+0.15 * \mathrm{SIAN}+0.16 * \mathrm{SITSS}+0.12 * \mathrm{SIPH}$

TABLE 2. National Water Quality Standards (NWQS) for Malaysia (DOE 2008)

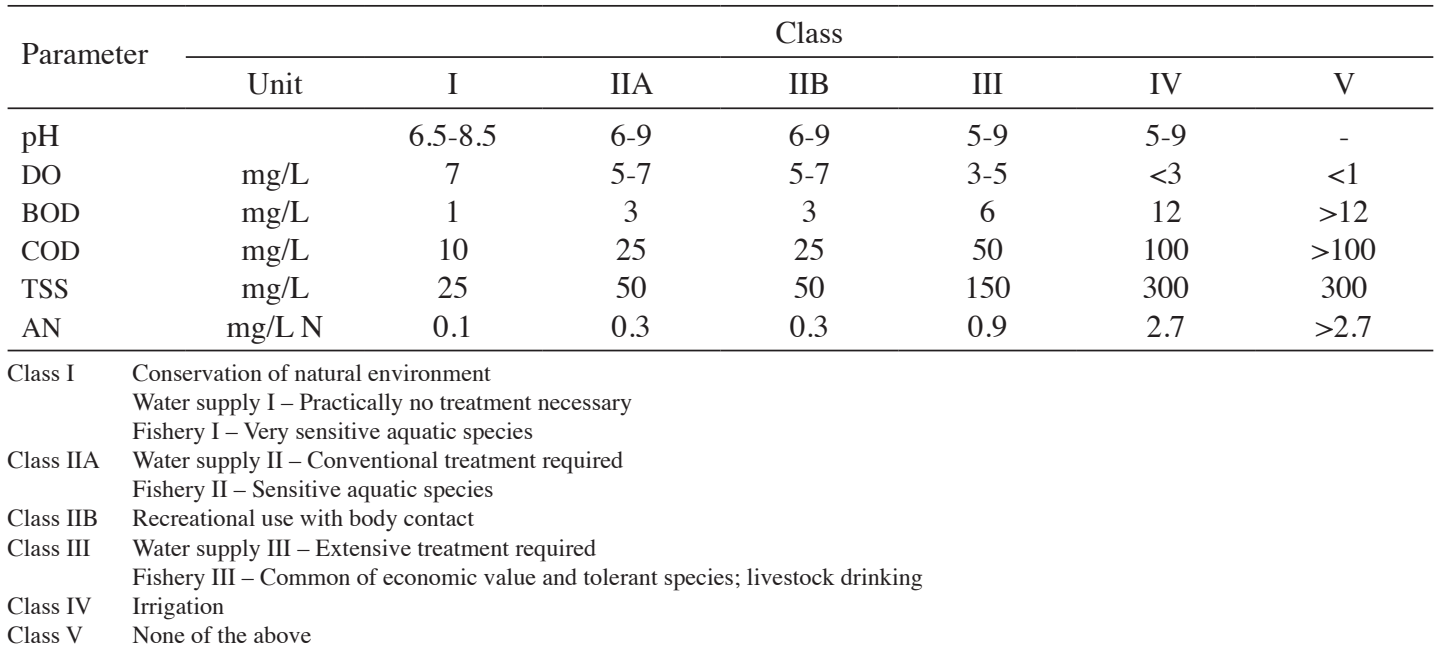




\section{MATERIALS AND METHODS}

\section{STUDY AREA AND SAMPLING STATIONS}

The Terengganu River basin is situated between a latitude of $4^{\circ} 40^{\prime}-5^{\circ} 20^{\prime} \mathrm{N}$ and a longitude of $102^{\circ} 30^{\prime}-103^{\circ} 09^{\prime} \mathrm{E}$ in the north eastern coastal region of Peninsular Malaysia (Figure 1). The main river in this basin is the Terengganu River, which flows from the upper watershed of Kenyir Lake to the South China Sea. The main tributaries feeding the Terengganu River are the Nerus, Tersat, Berang and Telemung Rivers, with a total catchment area of about 5000 $\mathrm{km}^{2}$. These rivers pass through different socio-economical activities area such as agricultural plantations (i.e. rubber, coconut and palm oil), farm, aquacultures, commercial industries, urban and rural settlements, reserves and forests. Population density is concentrated at the towns of Kuala Terengganu and Kuala Berang. The annual mean air temperature varies between 26 and $28^{\circ} \mathrm{C}$ and the annual rainfall is about $3300 \mathrm{~mm}$. The northeast monsoon season (November to March) brings heavy rains to this basin.

Monthly samplings were carried out at ten sampling stations within the basin from July until October 2008 which were in the pre-monsoon season (Figure 1). Each sampling was performed only in the morning section on the consecutive days in order to minimise the variation due to sampling time. Surface water samples for TSS and AN were collected using $10 \% \mathrm{HCl}$ pre-cleaned polyethylene bottles that were rinsed at least twice with surface water before being filled with the samples. In contrast, samples for AN were filled in the glass bottles. Samples for BOD analysis were collected in $300 \mathrm{~mL}$ amber glass bottles and were closed underwater. All water samples were placed in an ice chest to preserve and minimize contamination during transportation to the laboratory for further analysis. In addition, DO and $\mathrm{pH}$ were also measured in-situ using a YSI multiparameter (model 6600) data logger which was calibrated prior to use.

\section{SAMPLES ANALYSIS METHOD}

Samples were analysed following the methods outlined in the Standard Method for Examination of Water and Wastewater (APHA 2005). Briefly, the BOD values were determined based on the DO difference before and after the sample was stored in an incubator at $20^{\circ} \mathrm{C}$ for 5 days. The DO concentrations for the BOD values were measured using the desktop DO meter. The COD concentrations were based on open reflux methods in which the samples were refluxed for $2 \mathrm{~h}$ in an acidic medium, using potassium dichromate as an oxidizing agent. TSS were separated by filtering water samples through a pre-weighted membrane filter with a pore size of $0.45 \mu \mathrm{m}$ and then weighted the filter again after drying in an oven at $103-105^{\circ} \mathrm{C}$ to remove the water.

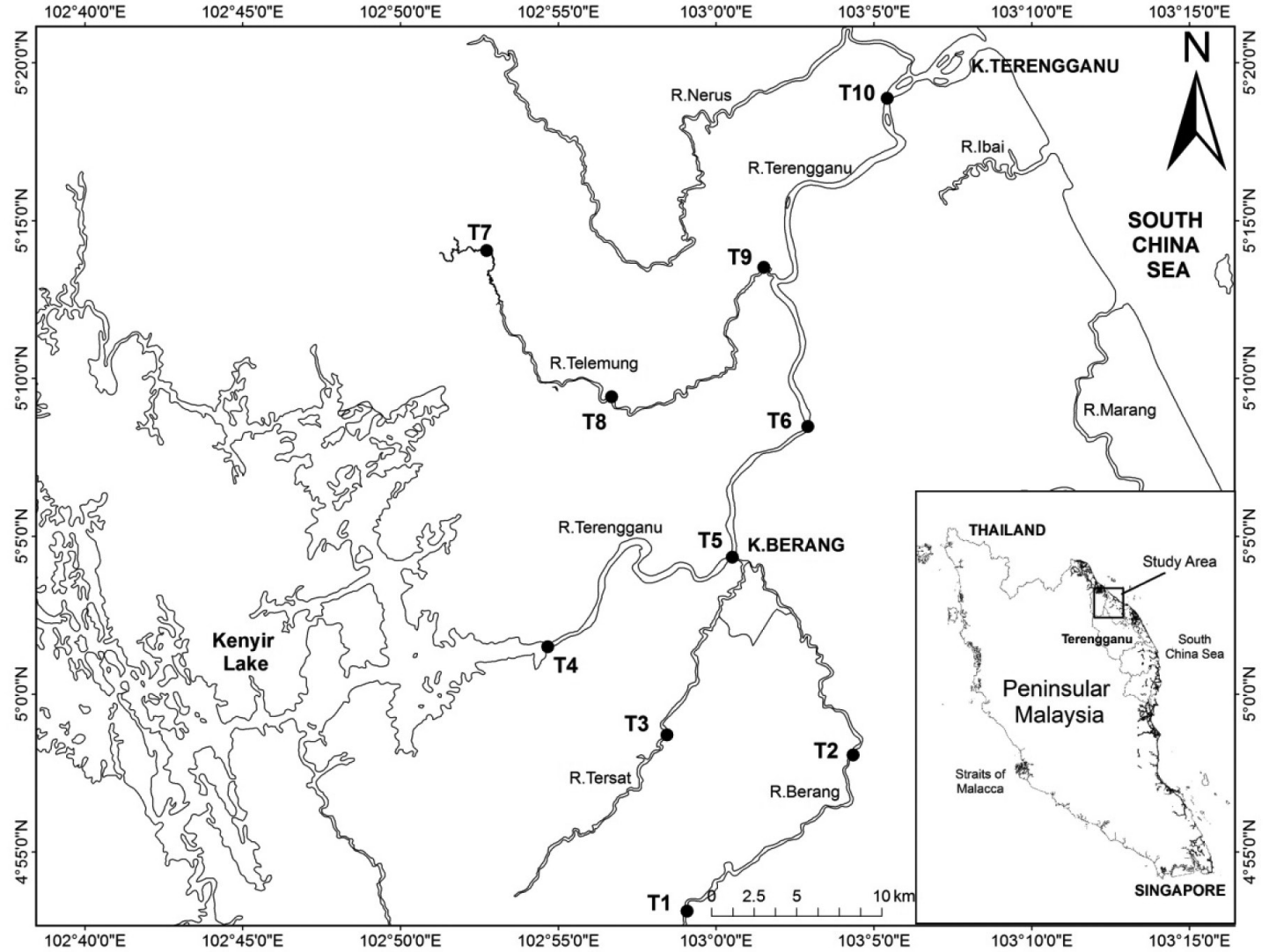

FIGURE 1. Sampling locations at the Terengganu River 
The filtered water samples were then used for analysis of AN by using the colorimetric method which the coloured solutions were measured by Shimazhu spectrophotometer model 1601.

\section{RESULTS AND DISCUSSION}

Figure 2 shows the data for the present study. The $\mathrm{pH}$ values varied from 5.20 to 7.76 with a mean value of $6.37 \pm 0.65$. The lowest and highest $\mathrm{pH}$ values were recorded at stations T9 and T1, respectively. A two-factor ANOVA test showed that the values were significantly different $(p<0.05)$ among the sampling stations and dates of sampling. In general, there was a decreasing trend of $\mathrm{pH}$ values in going from the upstream stations to the downstream stations. Based on NWQS classifications, the $\mathrm{pH}$ values for most of the stations were in Class I, with the exception of stations T5, T9 and T10, which were in Class III.
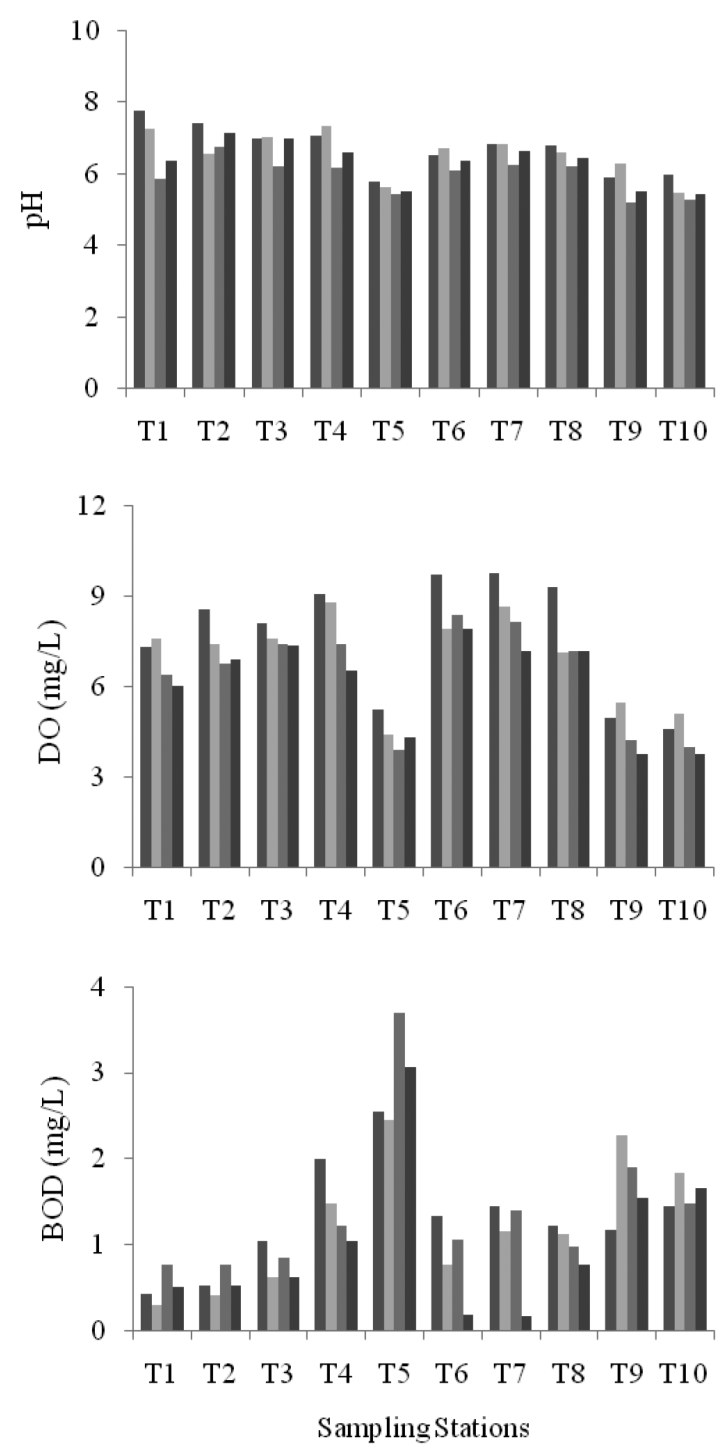

The DO concentrations recorded at station T10 and station T7, respectively, were between 3.99 and $9.74 \mathrm{mg} / \mathrm{L}$. The mean DO concentration within the basin was $6.78 \pm$ $1.76 \mathrm{mg} / \mathrm{L}$. A two-factor ANOVA test showed that the values were significantly different $(p<0.05)$ among sampling stations and dates of sampling. For all the survey, higher DO concentrations were recorded at stations T1, T2, T3, $\mathrm{T} 4, \mathrm{~T} 6, \mathrm{~T} 7$ and $\mathrm{T} 8$ while stations $\mathrm{T} 5, \mathrm{~T} 9$ and $\mathrm{T} 10$ recorded lower concentrations. In contrast to stations T5, T9 and T10 which were in Class III, the DO concentrations for most of the stations were in Class I.

The BOD and COD concentrations ranged from 0.29 to $3.69 \mathrm{mg} / \mathrm{L}$ and 4.32 to $48.50 \mathrm{mg} / \mathrm{L}$, respectively. The lowest BOD and COD concentrations were observed at stations $\mathrm{T} 1$ and $\mathrm{T} 2$, whereas the highest concentrations were recorded at stations $\mathrm{T} 5$ and $\mathrm{T} 10$. In addition, the mean BOD concentration was $1.24 \pm 0.78 \mathrm{mg} / \mathrm{L}$ whereas the recorded value for COD was $23.87 \pm 12.28 \mathrm{mg} / \mathrm{L}$. There
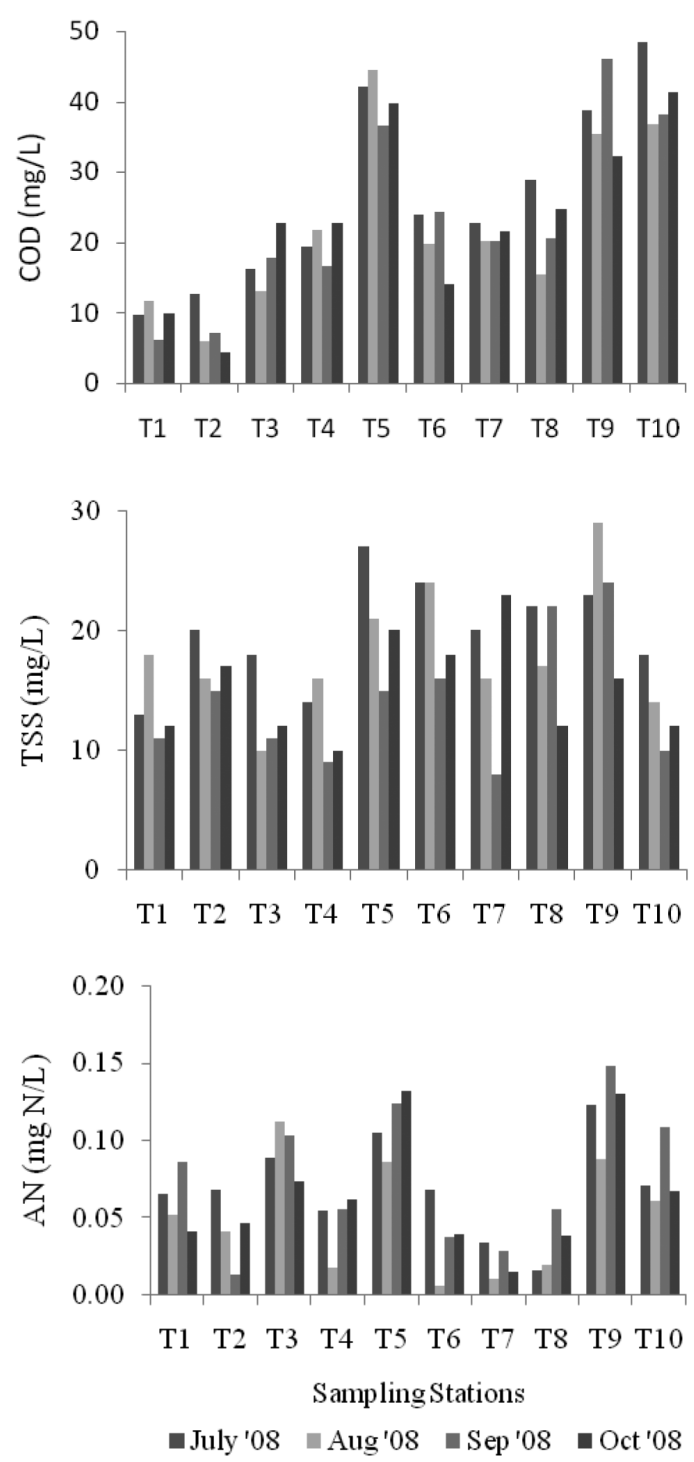

FIGURE 2. Variation of the parameters for the different sampling stations 
were significant differences $(p<0.05)$ among sampling stations and dates of sampling for both BOD and COD parameters. There was a general increasing trend in the BOD and COD concentrations from downstream to upstream stations with an exception of station T5 which recorded high concentrations for these two parameters. Based on NWQS classifications, the BOD concentrations for most of the stations were in Class I, with the exception of stations T4, T5, T9 and T10 which were in Class II. On the other hand, only stations $\mathrm{T} 1$ and $\mathrm{T} 2$ were in Class I while the others were either in Class II or III for the COD parameter. The level of TSS concentrations ranged from $9 \mathrm{mg} / \mathrm{L}$ (station T4) to $29 \mathrm{mg} / \mathrm{L}$ (station T9); the mean concentration recorded was $17 \pm 5 \mathrm{mg} / \mathrm{L}$. A two-factor ANOVA test showed that the concentrations were significantly different $(p<0.05)$ among sampling stations and dates of sampling. Although there was variability in TSS concentrations, in general, the concentration of TSS increased in going from the upstream stations to the downstream stations. With respect to TSS concentration, all stations were classified as Class I according to the NWQS classifications.

The concentration of AN varied between 0.006 and $0.148 \mathrm{mg} \mathrm{N} / \mathrm{L}$. Lower and higher concentrations of AN were measured at stations $\mathrm{T} 6$ and $\mathrm{T} 9$, respectively. The mean concentration recorded during the present study was $0.065 \pm 0.038 \mathrm{mg} \mathrm{N} / \mathrm{L}$. A two-factor ANOVA test showed that the concentrations were significantly different $(p<0.05)$ among the dates of sampling but showed no significant difference $(\mathrm{p}<0.05)$ among the sampling stations. In general, higher concentrations of AN were recorded at the middle and lower parts of the basin in comparison with the upper basin stations. Based on the NWQS classifications, all stations sampled were classified as Class I.

Figure 3 plots the variations in DOE-WQI values for the different sampling stations. The DOE-WQI values were in the range of 71.5-94.6\% (mean $86.9 \pm 7.4 \%$ ), which corresponded to a classification from slightly polluted to clean status. Minimum and maximum values were recorded at stations T9 and T2, respectively. A two-factor ANOVA test showed that the values were significantly different $(p<0.05)$ among sampling stations and dates of sampling. Within the basin, only stations $\mathrm{T} 5, \mathrm{~T} 9$ and $\mathrm{T} 10$ recorded lower $(>71 \%)$ DOE-WQI values whereas other stations showed higher $(>81 \%)$ readings.

In this study, the primary focus was to evaluate the water quality based on the DOE-WQI in Terengganu River basin. This study is important due to the fact that this basin is undergoing major development and vast population growth especially in Kuala Terengganu and Kuala Berang which are situated at the downstream and the middle part of the Terengganu River basin, respectively. Various anthropogenic activities such as industrial discharges, agricultural run-off and irrigation and municipal water pollution from homes and business can significantly contribute to the deterioration of water quality of the river and ultimately to the coastal areas of South China Sea.

As shown in Figure 2, there is a general trend of deteriorating water quality going from the upstream to the downstream stations. Such deterioration was particularly important at three main stations within the basin: stations T5, T9 and T10. At these particular stations, in general, the $\mathrm{pH}$ and DO concentrations were lower in comparison to that of other stations. In contrast, these stations also recorded high BOD, COD, TSS and AN concentrations. All these parameters contributed to low DOE-WQI values (Figure 3 ). This is probably due to the discharge of untreated municipal, industrial and agricultural wastes into the river systems as these stations are situated within the heavily populated areas of Kuala Terengganu and Kuala Berang. In addition, a small amount of aquaculture activities near the downstream stations influenced the results. Studies showed the wastes from these activities were characterized by high organic content leading to low pH, low DO and high AN values as a result of the decomposition processes (Bordalo et al. 2001; Mohd Rozali et al. 2006; Suratman et al. 2009, 2005).

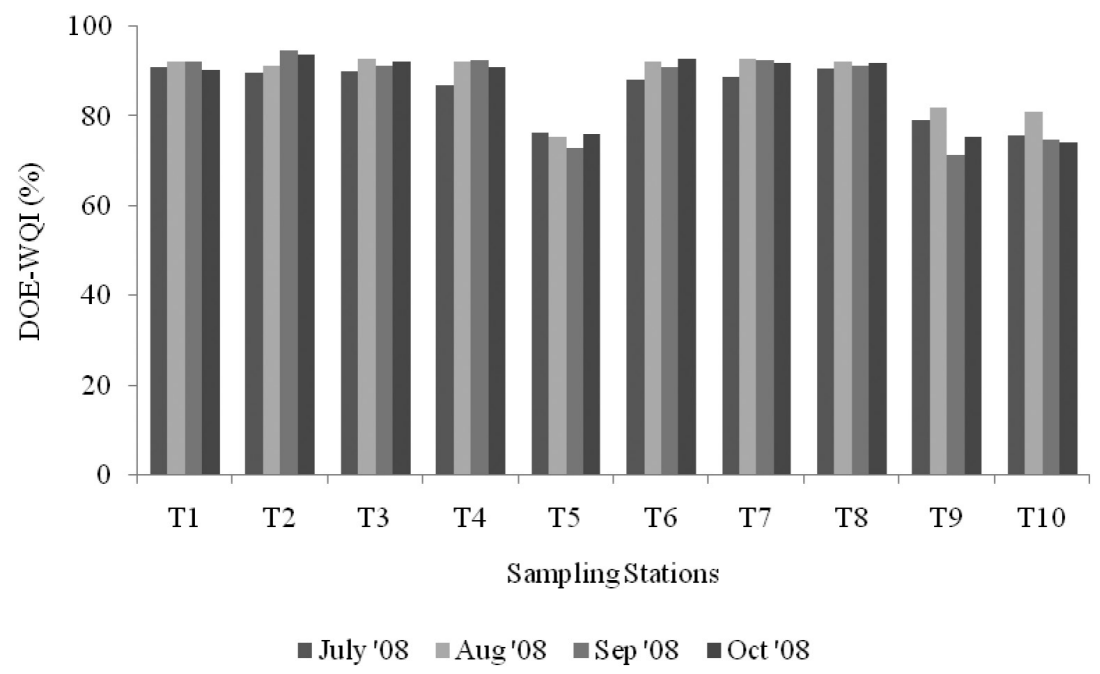

FIGURE 3. Variation of the DOE-WQI for the different sampling stations 
High BOD and COD concentrations, which coincided with low $\mathrm{pH}$, low DO and high AN values, also indicate the possibility of an organic pollution effect on water in these stations. BOD and COD concentrations indicate the amount of dissolved oxygen needed to decompose organic matter by microorganisms and chemicals, respectively. A high level of organic pollution in the aquatic system will increase the BOD and COD concentrations (Bordalo et al. 2001; Jonnalagadda \& Mhere 2001; Suratman et al. $2009,2005)$. The ratio of BOD/COD was calculated for each station as this ratio provides information with the extent of biodegradability of the organic matter in the study area (Kumar et al. 2010). The calculated ratio ranged from 0.01 to 0.12 suggesting that the organic matter in the effluent is difficult to biodegrade.

TSS is usually due to the introduction of external factors carried by runoff rain waters which can help increase the concentration of this parameter (Jonnalagadda \& Mhere 2001; Rossi et al. 2005; Suratman et al.2006). Contributions from natural phenomena, such as tidal effects (Suratman et al. 2005) and anthropogenic activities such as municipal, industrial, agricultural and aquaculture have also been reported to influence the TSS concentration (Atkinson et al. 2011; Bordalo et al. 2001; Suratman et al. 2009). In the present study, higher concentration of TSS recorded from middle to downstream stations were probably due to discharges of wastes from municipal, agricultural and aquaculture activities. Construction activities at the river banks near station T9 has probably caused the soils of the river bank to become looser and easily eroded. As a result, the TSS concentration was higher at this station. Station T10 is situated downstream of the basin and was expected to show a high TSS concentration due to its proximity to Kuala Terengganu but a low concentration of TSS was recorded. This was mostly due to the dilution effect from seawater as this station is located near the estuary.

\section{CONCLUSION}

The monitoring of DOE-WQI in the Terengganu River basin demonstrated that the water quality can be classified from slightly polluted to clean status with values ranging from 71.5 to $94.6 \%$ (mean $86.9 \%$ ). In general, low water quality was found at the middle and downstream stations. In contrast, high water quality was recorded at the upper stations of the basin. Based on the NWQS, most of the parameters measured remained in Class I from the upstream to the downstream stations. Various anthropogenic activities have caused significant changes in the water quality of the basin. The results presented here provide a baseline reference on the future monitoring of the Terengganu River basin.

\section{ACKNOWLEDGEMENTS}

The authors extent their appreciation to the Department of Chemical Sciences, Faculty of Science \& Technology, Universiti Malaysia Terengganu for the financial support.
The manuscript benefited from the comments of two anonymous reviewers.

\section{REFERENCES}

APHA (American Public Health Association). 2005. Standard Methods for Examination of Water and Wastewater. 21st ed. Washington D.C.

Atkinson, C.L., Golladay, S.W. \& First, M.R. 2011. Water quality and planktonic microbial assemblages of isolated wetlands in an agricultural landscape. Wetlands 31: 885-894.

Bordalo, A.A., Nilsumranchit, W. \& Chalermwat, K. 2001. Water quality and uses of the Bangpakong River (Eastern Thailand). Water Res. 35: 3635-3642.

DOE 2008. Malaysia Environmental Quality Report 2008. Department of Environment, Ministry of Natural Resources and Environment Malaysia, Kuala Lumpur. p. 86.

Horton, R.K. 1965. An index number system for rating water quality. J. Water Poll. Control Fed. 37: 300-306.

Inhaber, H. 1975. An approach to a water quality index for Canada. Water Res. 9: 821-833.

Jindal, R. \& Sharma, C. 2011. Studies on water quality of Sutlej River around Ludhiana with reference to physicochemical parameters. Environ. Monit. Assess. 174: 417-425.

Jonnalagada, S.B. \& Mhere, G. 2001. Water quality of the Odzi River in the eastern highlands of Zimbabwe. Water Res. 35: 2371-2376.

Kumar, A., Dhall, P. \& Kumar, R. 2010. Redefining BOD: COD ratio of pulp mill industrial wastewaters in BOD analysis by formulating a specific microbial seed. Int. Biodeter. Biodegr. 64: 197-202.

Landwehr, J.M. \& Deininger, R.A. 1976. A comparison of several water quality indexes. J. Water Poll. Control Fed. 48: 954-958.

Lim, S.H.,Abdullah, S. \& Mohd Rozali, O. 2006. Indeks Kualiti Air Negara (IKAN) Sistem Sungai Labu (In Malay). Malay. J. Anal. Sci. 10: 7-14.

Mohd Rozali, O., Mohd Talib, L., Abdullah, S. \& Muhamad Sanusi, S. 2006. Kesan aktiviti penanaman padi terhadap kualiti air (In Malay). Malay. J. Anal. Sci. 10: 233-242.

Pesce, S.F. \& Wunderlin, D.A. 2000. Use of water quality indices to verify the impact of Cordoba city (Argentina) on Suquia River. Water Res. 34: 2915-2926.

Rossi, L., Krejci, V., Rauch, W., Kreikenbaum, S., Fankhauser, R. \& Gujer, W. 2005. Stochastic modeling of total suspended solids (TSS) in urban areas during rain events. Water Res. 39: 4188-4196.

Sanchez, E., Colmenarejo, M.F., Vicente, J., Rubio, A., Garcia, M.G., Travieso,L.\& Borja, R. 2007. Use of the water quality index and dissolved oxygen deficit as simple indicators of watersheds pollution. Ecol. Indic. 7: 315-328.

Simoes, F.D.S., Moreira, A.B., Bisinoti, M.C., Gimenez, S.M.N. \& Yabe, M.J.S. 2008. Water quality index as a simple indicator of aquaculture effects on aquatic bodies. Ecol. Indic. 8: 476-484.

Sinsock, A.M., Wheater, H.S. \& Whitehead, P.G. 2003. Calibration and sensitivity analysis of a river water quality model under unsteady flow conditions. J. Hydrol. 277: 214-229.

Smith, D.G. 1990. A better water quality indexing system for rivers and streams. Water Res. 24: 1237-1244.

Srebotnjak, T., Carr, G., de Sherbinin, A. \& Rickwood, C. 2012. A global water quality index and hot-deck imputation of missing data. Ecol. Indic. 17: 108-119. 
Sun, P., Zhang, Q., Lu, X. \& Bai, Y. 2012. Changing properties at low flow of the Tarium River basin: Possible causes and implications. Quatern. Int. 282: 78-86.

Suratman, S., Awang, M., Loh, A.L. \& Mohd Tahir, N. 2009. Water quality index study in Paka River basin, Terengganu (in Malay). Sains Malaysiana 38: 125-131.

Suratman, S., Mohd Tahir, N., Lee, C.Y. \& Siti Rohayu, A.R. 2006. Monsoon effects on water quality in Besut River basin, Terengganu (in Malay). Malay. J .Anal. Sci. 10: 143-148.

Suratman, S., Ali, A. \& Lo, T.T. 2005. Determination of water quality index at Ibai River basin, Terengganu (in Malay). Sains Malaysiana 34: 55-59.

Zampella, R.A., Bunnell, J.F., Laidig, K.J. \& Procopio, N.A. 2006. Using multiple indicators to evaluate the ecological integrity of a coastal plain stream system. Ecol. Indic. 6: 644-663.

S. Suratman*, M.I. Mohd Sailan, Y.Y. Hee \& E.A. Bedurus Institute of Oceanography and Environment

Universiti Malaysia Terengganu

21030 Kuala Terengganu, Terengganu

Malaysia
M.T. Latif

School of Environmental and Natural Resource Sciences

Faculty of Science and Technology

Universiti Kebangsaan Malaysia

43600 Bangi, Selangor

Malaysia

*Corresponding author; email: miman@umt.edu.my

Received: 18 November 2013

Accepted: 31 May 2014 